\title{
Assistant Directors in the Columbia University Libraries
}

Columbia has kept its libraries and its library school under one head. It finds some justification for doing so in the size of the university. Perhaps it would be more accurate to say the justification lies in the number of officials in the university and in affiliated institutions who report directly to the president. The president of a large, complex university with a library school can follow, at least three courses: (I) place separate officers in charge of the library and the library school respectively, and have each one report directly to him; (2) place separate officers in charge of the library and the library school and have them report to him through some officer outside the library field, such as a vice president or dean of administration; or (3) place the library and the library school under one head.

If the library and the library school are placed under one head, as at Columbia, an abnormally wide span of control may simply be passed on from the president to the officer next in line, in which case, of course, the last state is hardly better than the first. The use of assistant directors in the Columbia libraries is explained by a desire to keep the span of control for the unified organization within manageable limits and the desire, at the same time, to have the strength of the combined staff measure up to the equivalent of the strength of two staffs if they stood separately, one for the libraries and one for the school of library service.

The object of this statement is to describe in some detail the work of the three assistant directors. The official job descriptions are being used for this purpose, although their form is not well suited to a publication of this kind. Three years ago, when the positions were created, the essential responsibilities of each of the positions stood out clearly but their outer perimeters blurred into one another. Experience and four competent young men $^{1}$-all with marked capacity for teamwork-showed us more clearly what the scope of each position should be. Recent revisions, involving minor changes in responsibility, have brought us to the point where for the first time public announcement of the job descriptions seems to be in order.

It should be added that the present scheme represents a fourth stage in the evolution of the administrative structure of the Columbia University Libraries. The first stage was one in which there was a chief librarian with no administrative assistance of any kind-a stage which is one of the common possessions of our libraries. The second stage was one when the director of libraries was also the dean of the school of library service and when he was supported on the library side by a librarian in direct charge of the daily operations of the libraries. The third stage was one in which the use of a single supporting administrative officer gave place to the use of three

1 These are, in the order of their appointment: Stephen A. McCarthy, Thomas P. Fleming, Maurice F. Tauber, and Charles W. Mixer. 
assistants to the director. This plan has much to be said in its favor in that it centralizes responsibility in one person, and that plan would probably still be in use but for the retirement of the director. His successor was far less familiar with the university and its libraries and felt it neces- sary to have recourse to the present scheme of organization.

Before enumerating the specific responsibilities of the assistant directors, it may be well to call attention to ten general functions which these three officers have in common. These may be listed as follows:

\section{FUNCTIONS OF ASSISTANT DIRECTORS}

I. Represent the director in organizing and operating that phase of the program of the libraries which falls in the service specified by the official title (General Administration; Readers' Services; Technical Services).

2. Represent the director on official committees or official occasions as requested and represent him in his absence in deciding questions which fall in the service administered.

3. Represent the director in dealing with faculty, students, and the extramural public of the university in matters which fall within the province of the service administered. (Director is the channel to president and deans.)

4. Maintain integrity of purpose in managing the library affairs of the university by staying in touch with the director and developing plans which express his aims and views. (This is a crucial step in a "decentralized" plan of administration such as ours, for on it depends the success of combining "self-starting" ability on the part of each assistant director and responsible direction of library affairs by a single head. This is the formula I should like to ask each man to apply to himself as the best means of helping the four of us make the strongest administrative team: outline carefully a program, step at a time; see that that program is approved; carry the program into effect, keeping in touch with headquarters by reporting favorable or unfavorable progress and final results; watch for developments including changed circumstances which call for a review of earlier decisions).

5. Report results to the director formally at the end of each fiscal year and informally as need may require.

6. Assemble the reports from within the service which are needed for administrative purposes.

7. Refer to other assistant directors matters which fall within their province.

8. Accord the other assistant directors the benefit of your opinion about questions on which they will pass but which affect your service.

9. Exercise initiative in developing publications which further the progress of the libraries.

I0. Serve in a staff capacity on all matters of library administration and present directly to the director recommendations on any subject the discussion of which may improve the work or service of the libraries.
Following are the responsibilities of the three assistant directorships in the order in which they were created. The order in which appointments were made to these three positions in the Columbia libraries was slightly different. 


\section{ASSISTANT DIRECTOR: GENERAL ADMINISTRATION}

\section{The Library Office}

I. Follows through on all administrative matters which overlap two or more services, which strike snags, etc.

2. Organizes the office staff and plans the duties of each member.

3. Arranges for the supervision necessary to insure efficiency, punctuality, etc.

4. Plans reception of visitors and telephone calls.

5. Oversees the office files.

6. Shares responsibility for office correspondence.

\section{Personnel}

7. Scouts for good employee talent.

8. Maintains a central file of eligible candidates for positions on the staff.

9. Receives requisitions for personnel needed by the departments. Normally these requisitions will be routed via the assistant director: readers' services or the assistant director: technical services, whichever is appropriate.

10. Recruits applicants for specific vacancies which occur.

II. Acquaints such administrative officers as have an interest in a vacancy with available candidates and secures their judgment about them.

12. Organizes relevant information and presents his recommendation to director, or acts for him, as directed.

13. Makes up the library payroll.

14. Cooperates with other assistant directors and heads of departments in helping the individuual staff member maintain a high level of efficiency and interest in his work.

I5. Has charge of off-duty activities planned for the library staff.

16. Approves programs of study of members of the staff.
17. Approves arrangements whereby members of the staff may teach or assume any other duties not a part of the library job.

18. Maintains, through cooperation of other assistant directors and heads of departments, a central vacation schedule.

19. Conducts interviews with staff, including exit interviews.

20. Maintains personnel records.

21. Devises measures for fair appraisal of the work of members of the staff.

22. Reviews staff complaints regarding classification and recommends action.

23. Serves as communications officer by channeling information of general interest to members of the library staff. Examples: holidays, biographical information about a new head of a department, change in the retirement system, etc.

24. Assists in maintaining high standards of personnel management and in dovetailing the personnel work of the libraries with that of the rest of the university.

25. Conducts continuous study of problems of personnel management.

\section{Controller of the Budget}

26. Analyzes financial requirements of the library system and presents his recommendations for use in preparation of the budget for each new fiscal year.

27. Revises in accordance with approved procedure internal allotments for a fiscal year which are authorized for any purpose such as book funds, binding funds, etc.

28. Keeps expenditures within approved limits.

29. Devises accounting procedures to tell the library administration what it needs to know about library expenditures.

30. Serves as connecting link between the business operations of the libraries and the bursar's office. 
31. Signs invoices for books, etc., in absence of assistant director: technical services.

32. Signs requests for cancelation in absence of assistant director: technical services.

33. Encourages and conducts study of expenditures for the purpose of helping the library administration appraise its fiscal policy.

\section{The Physical Plant}

34. Assigns studies.

35. Issues keys.

36. Looks after the cleaning, maintenance, and repair of Butler Library and library quarters elsewhere on the campus.

37. Arranges for opening and closing the building and for any temporary use of library space which is out of the ordinary.

38. Oversees regulations governing public use of library quarters.

39. Acquaints the public with hours of opening, location of offices, reading rooms, etc.

40. Serves as liaison officer in relation to buildings and grounds.

41. Serves as liaison officer in relation to the school of library service regarding the quarters of the school.

42. Looks after physical arrangements for the convenience of the staff and the public.
43. Participates in planning changes in the physical plant. Changes affecting the readers' services or the technical services are to be cleared by the assistant director whose service is affected before presentation to the assistant director: general administration.

\section{Physical Property of the Libraries}

44. Purchases supplies and equipment.

45. Oversees the distribution, location, or relocation of this property.

46. Controls physical facilities purchased with library funds.

47. Plans repair and replacement program.

\section{Relations with the General Public}

48. Receives visitors and looks after their welfare.

49. Takes the initiative in cooperation with the university public relations office in disseminating information about the activities of the libraries.

50. Stimulates planning of library publications and serves as general editor for these publications.

5I. Prepares reports and news releases.

52. Studies forms used in collecting statistics for the libraries.

53. Supplies information (including statistics) about the libraries.

\section{ASSISTANT DIRECTOR: TECHNICAL SERVICES}

\section{Book Selection}

I. Cooperates in the selection of material and, in the absence of the assistant director: readers' services, makes final decisions in matters of selection.

\section{Acquisition}

2. Organizes procurement machinery.

3. Handles acquisition of library material.
4. Selects and handles relations with bookdealers and publishers.

5. Arranges for procurement through exchange.

6. Assists in decisions concerning duplicates; organizes work involved in adding duplicates.

7. Assists in making decisions regarding discarding; organizes work involved in discarding. 
8. Effects transfer of gifts to the university.

9. Prepares letters for signature in case of gift; signs printed and engraved forms.

ı. Carries on correspondence directly or through the director in connection with gifts; conducts arrangements to secure gifts.

II. Signs orders (personal) of staff members ; signs order cards in absence of readers' services.

\section{Cataloging and Classification}

12. Conducts a continuous study of methods of cataloging and otherwise organizing the resources of the modern library.

13. Plans the flow of work involved in organizing library materials by approved methods.

\section{Binding}

I4. Heads conservation program for the general run of books.

15. Draws up and reviews periodically specifications for library binding.

I6. Studies methods, equipment, materials, and cost.

\section{Photographic Reproduction}

I7. Acquaints scholars with the uses of photographic reproduction.

18. Plans photographic reproduction projects with a view to getting the fullest use of this medium for the library.

I9. Brings the full impact of developments in this field to the councils of the library staff.

\section{Organization and Supervision}

20. Conducts continuous study of the way work in the technical services is organized.

21. Reports conditions to director and clears with him before launching any important change in program or in the structure of the organization.

22. Works out, in cooperation with appropriate officers of the staff, the "positionizing" of work in the technical services (that is, the breaking down of the total volume of work to be done into specific jobs).

23. Works out, or approves, specifications for all positions.

24. Makes provision for responsible and effective supervision of all work and personnel of the technical services.

25. Aids in putting each person to work at his highest level of performance.

26. Delegates to supervisory officers of the staff such duties as are consistent with good organization and sound administration.

27. Participates in devising machinery for evaluating performance of the individual members of the staff.

\section{Staff for Technical Services}

28. Interviews prospective staff members for technical services; lends assistant director: general administration full cooperation in recruiting.

29. Conducts exit interviews. See also assistant director : general administration.

30. Assigns duties, approves schedules, etc., in accordance with approved library policy.

31. Confers with assistant director: general administration in regard to personnel problems.

32. Notifies assistant director: general administration of impending vacancies or authorizes arrangements by which the head of the department makes such notifications. (The intent of this statement is to insure use of the assistant director: technical services as a channel of action in personnel matters.) 


\section{Budget Preparation and Book Purchases}

33. Receives budget recommendations from all departments in the technical services.

34. Submits budget recommendations for salaries and wages in the technical services for the use of the assistant director: general administration in budget preparation.

35. Summarizes and analyzes expenditures for library additions and library binding.

36. Spends funds for library additions and library binding in accordance with approved allotments, using accounting procedures devised by the assistant director: general administration.

37. Informs assistant director: readers' services when any book fund is exhausted before the end of the fiscal year.

38. Acts on decisions which make transfers of funds.

39. Originates requests for supplies and equipment for technical services and forwards them to the assistant director: gen- eral administration; signs requisitions in the absence of the assistant director: general administration.

40. Signs invoices for book purchases.

41. Signs order cards in absence of assistant director: readers' services.

42. Signs invoices for book sales.

43. Signs requests for cancelation.

44. Signs financial clerk's orders in the absence of the assistant director: general administration.

45. Signs supply clerk's orders in the absence of the assistant director: general administration.

\section{Reports}

46. Analyzes, through statistical and other records and through the assistance of the staff, the work of the technical services with a view to securing the information necessary for intelligent management and over-all planning.

47. Establishes the necessary procedures for accumulating such information.

48. Reports achievements annually or as need requires.

\section{ASSISTANT DIRECTOR: READERS' SERVICES}

\section{Library Resources}

I. Organizes book selection activities to support the university's program of instruction and research.

2. Promotes rounded development of the library resources of the university. The phrase "rounded development" takes into account the fact that the university has library needs of long range which are not always met by satisfying the immediate needs of the current program of instruction and research.

3. Puts the specialized knowledge of the staff to full use in developing the resources of the libraries.

4. Decides whether duplicate copies of titles or sets should be purchased.
5. Serves as library admissions authority. The responsibility for deciding whether a gift pamphlet is to be accessioned, whether a doubtful recommendation for the purchase of a book is to be approved, whether an item is to be procured in the original, on microfilm, or in photostat, and for deciding other questions of this sort is centralized in the assistant director: readers' services. Heavy responsibility for decision on whether given titles are to be made part of the holdings of the libraries will in actual practice be delegated to other key members of the staff, notably. college, school, and departmental libraries, but centralization of final responsibility will provide the mechanism for planning and getting prompt decisions 
when and as needed.

6. Decides where library material should be located. This includes decisions on requests for transfer from one location to another.

7. Plans and directs the checking of current bibliographies.

8. Plans and directs the checking of dealers' catalogs and book lists.

9. Authorizes by signature orders proposed by faculty and departmental librarians.

I0. Passes.on the purchase of collections or the acquisition of material by gift or exchange.

I I. Takes initiative in developing plans which will insure proper housing and care of the collections and will facilitate reader access and use; turns over any such plans, when drafted, to the assistant director: general administration, whose task it is to - handle any physical construction or alteration.

\section{Service to Readers}

12. Gathers and organizes information about use problems of the library system as a whole.

13. Studies existing services with the aid of other library officers to determine how successful practices in one department can be used in another, how any limitation in the service program of the libraries can be corrected, etc.

I4. Coordinates the various services to readers with the object of having the reader derive maximum benefit from them.

15. Enlists the assistance of readers and staff in promoting mutual understanding and goodwill.

16. Develops information through records, reports, etc., about service achievements of the libraries.

17. Organizes and disseminates information about the library collections of the uni- versity which will be of use to present and prospective readers.

\section{Reader Relations}

18. Plans instruction in the use of library facilities.

19. Passes on applications for the use of the libraries by persons not connected with the university.

20. Regulates the use of the libraries in accordance with approved library and university policy.

2I. Provides for reader access, for protection against unnecessary loss, etc.

\section{Organization and Supervision}

22. Conducts continuous study of the way the work in the readers' services is organized.

23. Reports conditions to the director and clears with him before launching any important change in program or in the structure of the organization.

24. Works out, in cooperation with proper officers of the staff, the "positionizing" of work in the readers' services (that is, the breaking down of the total volume of work to be done into the specific jobs).

25. Works out, or approves, specifications for all positions.

26. Makes provision for responsible and effective supervision of all work and personnel of the readers' services.

27. Aids in putting each person to work at his highest level of performance.

28. Delegates to supervisory officers of the staff such duties as are consistent with good organization and sound administration.

29. Participates in devising machinery for evaluating performance of individual members of the staff.

\section{Staff for Readers' Services}

30. Interviews prospective staff members of readers' services. 
3r. Lends assistant director: general administration full cooperation in recruiting.

32. Conducts exit interviews. See also assistant director : general administration.

33. Assigns duties, approves schedules, etc., in accordance with approved library policy.

34. Confers with assistant director: general administration in regard to personnel problems.

35. Notifies assistant director: general administration of impending vacancies or authorizes arrangements by which the head of the department makes such notification. (The intent of this statement is to insure use of the assistant director: readers' services as a channel of action of personnel matters.)

\section{Budget Preparation and Allocation of Funds}

36. Receives budget recommendations from all departments in the readers' services.
37. Submits budget recommendations for salaries and wages in the readers' services for use of the assistant director: general administration in the preparation of the budget.

38. Submits budget recommendations for library additions and library binding.

39. Recommends allocation of the budget for library additions and library binding.

40. Recommends internal adjustments of the budget for library additions.

\section{Reports}

41. Analyzes, through statistical and other records and through the assistance of the staff, the work of the readers' services with a view to securing the information necessary for intelligent management and over-all planning.

42. Establishes the necessary procedures for accumulating such information.

43. Reports achievements annually or as need requires.

\section{International Relations}

(Continued from page 339)

realization by administrators that it will take a good deal of trouble to find the best means of using foreign librarians and, at the same time, preventing their American experience from becoming merely a year of unenlightening clerical drudgery.

If an international program for exchange of personnel involving hundreds of librarians per year would be very difficult to arrange, its results are almost equally hard to estimate. Any proposal that a year of work in another country be made a normal part of the preparation of librarians is at least as novel as was the first library school.

Such a program will have a negligible chance of materializing unless American librarians-public, school, special, college, and research-want it very much and go after it vigorously. Most librarians have never taken part actively in international library relations; but there has never been an international project that promised to benefit most of them directly. International exchange of personnel on a large scale, if it is desirable, would be as novel in this respect as in any other. If librarians approve of the idea and if enough of them possess some of the qualities that have distinguished Charles Harvey Brown throughout his career, fears of novelty or difficulty will not stop them from doing something about it. 